\title{
A STUDY OF CLINICO-HISTOPATHOLOGICAL CORRELATION OF CUTANEOUS MANIFESTATIONS IN LEPROSY
}

Rahul P1, Jonnalagadda Balachandrudu², Shivakumar V3

${ }_{1}^{1}$ Senior Resident, Department of DVL, Sri Venkateswara Medical College/SVRRGG Hospital, Tirupati, Andhra Pradesh, India. ${ }^{2}$ Assistant Professor, Department of Dermato-Venereology, Sri Venkateswara Medical College/SVRRGG Hospital, Tirupati, Andhra Pradesh, India.

3 Professor and HOD, Department of DVL, PESIMSR, Kuppam, Andhra Pradesh, India.

ABSTRACT
BACKGROUND
Leprosy is one of the oldest and chronic infectious diseases known to human beings caused by Mycobacterium leprae. The disease
still carries a grave social stigma and ostracism, which compels the patients to hide the disease. Leprosy continues to be an
important public health problem in most parts of Asia, especially India. ${ }^{1}$ Leprosy is a progressive, chronic granulomatous disease of
the peripheral nerves and skin and other tissues such as mucous membranes, muscles and reticuloendothelial system. The disease
presents in various clinico-pathological forms depending on the immune status of the host. The disease spectrum has been
characterised in a number of classification systems, most widely being the Ridley-Jopling.
Aim- Fifty cases were taken to correlate clinical diagnosis with histopathological findings.

\section{MATERIALS AND METHODS}

All clinically suspected Leprosy patients attending Department of DVL were included in this study. History was taken in detail and complete examination of patients carried out, particularly with reference to skin, nerves and sensory disturbances. Slit skin smear was taken from the patients with specific findings. The biopsies were taken from the most active and untampered lesions including the margin of the lesion and sent to the Pathology Department in 10\% neutral buffered formalin. The histopathological diagnosis was made based on the scheme put forth by Ridley and Jopling.

\section{RESULTS}

The present study comprised of 50 patients, 33 were male (66\%) and 17 female (34\%) with a male: female ratio of 1.9: 1 . Table 1 shows the distribution of patients according to age group and gender. Majority of the patients (11 patients: 7 males and 4 females) were between 31-40 years of age, whereas least affected were below 10 years ( 2 female patients). The mean age of the patients studied was $41.3441 .34 \pm 17.104$. The range of youngest patient is 7 years old female and the oldest patient is 75 years old male. With regard to patient's occupation, the largest group included are 20 farmers (40\%) followed by 12 daily labour ers (24\%), students and housewife are equal percentage (12\%), whereas only $2.0 \%$ of the patients are employees. The distribution of these cases based on Ridley and Jopling clinical and histopathological classification is shown in Table 4. It is clearly evident from Table 4 that clinically majority of the patients (40\%) belonged to Lepromatous Leprosy (LL) group followed by borderline tuberculoid (BT) group (24\%), tuberculoid leprosy (TT) group (14\%) and mid-borderline (BB) group and indeterminate leprosy (IL) group with $6 \%$ to $4 \%$ each. Histopathologically, majority of the cases 32\% belonged to Lepromatous Leprosy (LL) followed by BT (18\%), BL (16\%), TT and IL (12\% each). Among cases with negative slit skin smear were 40 patients. 10 patient's slit skin smears were positive in $20 \%$ of patients. Out of 20 patients, $2+$ for 2 patients, $3+$ for 7 patients and BI was maximum $4+$ for 1 patient. The correlation between clinical and histopathological classification is shown in Table No. The overall concordance between the clinical and histopathological agreement was seen in 15 (34.5\%) cases and maximum. Clinico-histopathological correlation was seen in BB (100\%) followed by TT (57.1\%), BT (50\%), IL and BL (33.3\%) and 0\% in LL. The concordance rate was lower in the borderline groups with $33.3 \%$ in BL, 33\% in IL and least concordance of $16.7 \%$ in LL. However, the concordance for TT was higher than the borderline groups with 57.1\%. Histopathological analysis of the cases in the present study as shown in Table 3 was carried out with due attention to the epidermal atrophy, presence of clear subepidermal zone, dermal inflammatory infiltrate, presence and composition of granulomas, presence of giant cells and relative proportion of lymphocytes and foamy histiocytes in accordance with Ridley and Jopling histopathological criteria. Out of the 50 patients included in the study, 15 (30\%) presented with a clinical suspicion of paucibacillary leprosy and $35(70 \%)$ of multibacillary leprosy. From the chi-square output table, we see that no significance level has been achieved. McNemar Bowker test table showing no systematic association between the above two variables at $95 \%$ level of confidence. Hence, it concludes that there is no significant relationship between age wise patients and histopathological diagnosis.

\section{CONCLUSION}

Leprosy, though reported to be eliminated, still continue to be one of the common infectious diseases in India. Skin biopsy is the useful tool in clinical diagnosis of leprosy as well as therapeutic guide.

\section{KEY WORDS}

Mycobacterium Leprae, Leprosy, Histopathology, Ridley-Jopling Classification.

HOW TO CITE THIS ARTICLE: Rahul P, Balachandrudu J, Shivakumar V. A study of clinico-histopathological correlation of cutaneous manifestations in leprosy. J. Evolution Med. Dent. Sci. 2018;7(46):4950-4955, DOI: 10.14260/jemds/2018/1102 
'Financial or Other Competing Interest': None.

Submission 01-10-2018, Peer Review 27-10-2018,

Acceptance 02-11-2018, Published 12-11-2018.

Corresponding Author:

Dr. Jonnalagadda Balachandrudu,

Assistant Professor,

Sri Venkateswara Medical College,

SVRRGG Hospital, Tirupati,

Andhra Pradesh, India.

E-mail: jonnalagaddabalu@gmail.com

DOI: $10.14260 /$ jemds/2018/1102

\section{(c) $(i)(5$}

\section{BACKGROUND}

Leprosy is one of the oldest and chronic infectious diseases known to human beings caused by Mycobacterium leprae. The disease still carries a grave social stigma and ostracism, which compels the patients to hide the disease. Leprosy continues to be an important public health problem in most parts of Asia, especially India. ${ }^{1}$

Leprosy is a progressive, chronic granulomatous disease of the peripheral nerves and skin and other tissues such as mucous membranes, muscles and reticuloendothelial system. The disease presents in various clinico-pathological forms depending on the immune status of the host. The disease spectrum has been characterised in a number of classification systems, most widely being the Ridley-Jopling classification. In this classification, leprosy has been divided into five groups as Tuberculoid (TT), Borderline Tuberculoid (BT), Mid-Borderline (BB), Borderline Lepromatous (BL) and Lepromatous (LL). ${ }^{2,3}$

Diagnosis of leprosy is based on different clinical parameters, which involves detailed examination of skin lesions and peripheral nerves. Demonstration of acid-fast bacilli in slit skin smears by Ziehl-Neelsen's staining also aids in diagnosis of leprosy. A reliable diagnosis hinges around a good histopathological diagnosis and demonstration of bacilli in histopathological sections. 4,5 Clinical classification gives recognition only to gross appearances of the lesions, while the parameters used for the histopathological classification are well defined, precise and also take into account the immunological manifestations which enable it to successfully bridge the pitfalls in leprosy diagnosis. Histopathology provides confirmatory information for suspected cases, which can be missed in clinical practice or epidemiological studies and helps in exact typing. ${ }^{6}$

\section{Aims and Objectives of the Study}

1. To study the clinical pattern of the disease.

2. To correlate histopathological findings with AFB (Acid Fast Bacilli - M. Leprae) status.

3. To correlate clinical diagnosis with histopathological findings.

\section{Source of Data}

A hospital-based, clinical, observational study was conducted in the Department of Dermatology, Venereology and Leprosy. Fifty patients clinically diagnosed as having Leprosy were taken up for the study.

\section{Sample Size}

50 .

\section{MATERIALS AND METHODS}

Method of Collection of Data

All clinically suspected Leprosy patients attending Department of DVL were included in this study. The history was taken in detail and complete examination of patients carried out, particularly with reference to skin, nerves and sensory disturbances.

Slit skin smear was taken from the patients with specific findings. The biopsies were taken from the most active and untampered lesions including the margin of the lesion and sent to the Pathology Department in 10\% neutral buffered formalin. The histopathological diagnosis was made based on the scheme put forth by Ridley and Jopling.

\section{Inclusion Criteria}

The study includes all clinically diagnosed cases of leprosy attending Department of DVL.

\section{Exclusion Criteria}

All cases of leprosy treated earlier. Patients with HIV infection.

\section{Statistical Analysis}

Statistical analysis of our study was performed using the software Statistical Package of Social Science version 20 (SPSS). The Clinical diagnosis of the leprosy cases (As provided by Department of Dermatology) using Ridley and Jopling scale correlated with the results of histopathological examination of their respective biopsies were analysed and matched using Kappa and McNemar test. A p $<0.05$ was considered to be statistically significant. The data were reported as mean \pm SD and frequency.

\section{RESULTS}

The present study comprised of 50 patients, 33 were males (66\%) and 17 females (34\%) with a male: female ratio of 1.9: 1 .

Table 1 shows the distribution of patients according to age group and gender. Majority of the patients (11 patients: 7 males and 4 females) were between 31 - 40 years of age, whereas least affected were below 10 years (2 female patients). The mean age of the patients studied was $41.3441 .34 \pm 17.104$. The range of youngest patient is 7 years old female and the oldest patient is 75 years old male.

\begin{tabular}{|c|c|c|c|}
\hline \multirow{2}{*}{ Age } & \multicolumn{2}{|c|}{ Gender } & \multirow{2}{*}{ Total } \\
\hline & Male & Female & \\
\hline 0 - 10 Years & 0 & 2 & 2 \\
\hline $11-20$ Years & 1 & 2 & 3 \\
\hline $21-30$ Years & 7 & 3 & 10 \\
\hline $31-40$ Years & 7 & 4 & 11 \\
\hline $41-50$ Years & 5 & 4 & 9 \\
\hline $51-60$ Years & 6 & 2 & 8 \\
\hline$>60$ Years & 7 & 0 & 7 \\
\hline Total & 33 & 17 & 50 \\
\hline \multicolumn{4}{|c|}{ Mean Age: $41.34 \pm 17.104$} \\
\hline
\end{tabular}

NS- Not Significant, Chi-square test- $\mathrm{P}>0.05$ 


\begin{tabular}{|c|c|c|}
\hline Gender & Frequency & Percentage \\
\hline Male & 33 & $66.0 \%$ \\
\hline Female & 17 & $34.0 \%$ \\
\hline Total & $\mathbf{5 0}$ & $\mathbf{1 0 0 . 0 \%}$ \\
\hline \multicolumn{2}{|c|}{ Table 2. Sex Wise distribution of Patients } \\
\hline
\end{tabular}

\begin{tabular}{|c|c|c|}
\hline Occupation & Frequency & Percentage \\
\hline Farmer & 20 & $40 \%$ \\
\hline Daily Labourer & 12 & $24 \%$ \\
\hline Student & 6 & $12 \%$ \\
\hline Housewife & 6 & $12 \%$ \\
\hline Lab Technician & 1 & $2 \%$ \\
\hline Business & 2 & $4 \%$ \\
\hline Factory Worker & 2 & $4 \%$ \\
\hline Employee & 1 & $2 \%$ \\
\hline Total & 50 & $100 \%$ \\
\hline
\end{tabular}

With regard to patient's occupation, the largest group included are 20 farmers (40\%) followed by 12 daily labourers (24\%). Students and housewife are equal percentage $(12 \%)$, whereas only $2.0 \%$ of the patients are employees.

\begin{tabular}{|c|c|c|c|c|c|}
\hline $\begin{array}{c}\text { Clinical } \\
\text { Type }\end{array}$ & Frequency & $\mathbf{\%}$ & $\begin{array}{c}\text { Histopathological } \\
\text { Type }\end{array}$ & Frequency & $\%$ \\
\hline BB & 2 & $4 \%$ & BB & 2 & $4 \%$ \\
\hline BT & 12 & $24 \%$ & BT & 9 & $18 \%$ \\
\hline BL & 6 & $12 \%$ & LL & 16 & $32 \%$ \\
\hline TT & 7 & $14 \%$ & TT & 6 & $12 \%$ \\
\hline LL & 20 & $40 \%$ & BL & 8 & $16 \%$ \\
\hline IL & 3 & $6 \%$ & IL & 6 & $12 \%$ \\
\hline NS & 0 & 0 & NS & 3 & $6 \%$ \\
\hline Total & $\mathbf{5 0}$ & $\mathbf{1 0 0 \%}$ & Total & $\mathbf{5 0}$ & $\mathbf{1 0 0} \%$ \\
\hline \multicolumn{7}{|c|}{ Table 4. Clinical Diagnosis of Patient } \\
\hline
\end{tabular}

$\mathrm{TT}=$ Tuberculoid; $\mathrm{BT}=$ Borderline Tuberculoid; $\mathrm{BB}=$ Borderline Borderline; $\mathrm{BL}=$ Borderline Lepromatous, $\mathrm{LL}=$ Lepromatous, $\mathrm{IL}=$ Indeterminate Leprosy.

The distribution of these cases based on Ridley and Jopling clinical and histopathological classification is shown in Table 4. It is clearly evident from Table 4 that clinically majority of the patients (40\%) belonged to Lepromatous Leprosy (LL) group followed by Borderline Tuberculoid (BT) group (24\%), Tuberculoid Leprosy (TT) group (14\%) and Mid-Borderline (BB) group and Indeterminate Leprosy (IL) group with $6 \%$ to $4 \%$ each. Histopathologically, majority of the cases $32 \%$ belonged to Lepromatous Leprosy (LL) followed by BT (18\%), BL (16\%), TT and IL are (12\% each).

\begin{tabular}{|c|c|c|}
\hline SSS Grading & Frequency & Percentage \\
\hline 0 & 40 & $80 \%$ \\
\hline $2+$ & 2 & $4 \%$ \\
\hline $3+$ & 7 & $14 \%$ \\
\hline $4+$ & 1 & $2 \%$ \\
\hline Total & $\mathbf{5 0}$ & $\mathbf{1 0 0} \%$ \\
\hline \multicolumn{2}{|c|}{ Table 5. Slit Skin Smear of Patients (BI) }
\end{tabular}

Among cases with negative slit skin smear were 40 patients. 10 patients slit skin smears were positive in $20 \%$ of patients. Out of 20 patients $2+$ for 2 patients, $3+$ for 7 patients and $\mathrm{BI}$ was maximum $4+$ for 1 patient.

\begin{tabular}{|c|c|c|c|c|c|c|c|c|c|}
\hline \multirow{2}{*}{$\begin{array}{l}\text { Clinical } \\
\text { Type }\end{array}$} & \multirow{2}{*}{\begin{tabular}{|c|} 
Clinical \\
Diagnosed \\
Cases \\
\end{tabular}} & \multicolumn{7}{|c|}{ Histopathological Diagnosis } & \multirow{2}{*}{$\begin{array}{l}\% \text { of } \\
\text { Parity }\end{array}$} \\
\hline & & BB & BT & BL & TT & $\mathbf{L L}$ & IL & NS & \\
\hline BB & 2 & 2 & 0 & 0 & 0 & 0 & 0 & 0 & 100.0 \\
\hline BT & 12 & 0 & 6 & 0 & 2 & 1 & 3 & 0 & 50.0 \\
\hline $\mathrm{BL}$ & 6 & 0 & 1 & 2 & 0 & 14 & 1 & 2 & 33.3 \\
\hline TT & 7 & 0 & 1 & 0 & 4 & 0 & 1 & 1 & 57.1 \\
\hline LL & 20 & 0 & 0 & 6 & 0 & 0 & 0 & 0 & 0.0 \\
\hline IL & 3 & 0 & 1 & 0 & 0 & 1 & 1 & 0 & 33.3 \\
\hline NS & 0 & 0 & 0 & 0 & 0 & 0 & 0 & 0 & 0.0 \\
\hline Total & 50 & 2 & 9 & 8 & 6 & 16 & 6 & 3 & 34.5 \\
\hline \multicolumn{10}{|c|}{$\begin{array}{l}\text { Table 6. Correlation of Clinical and Histopathological } \\
\text { Classification in Leprosy Cases }\end{array}$} \\
\hline
\end{tabular}

Kappa $=0.566$. The strength of agreement is considered to be above moderate $\mathrm{p}=0.000$ (Significant).

The correlation between clinical and histopathological classification is as shown in Table No. 6. The overall concordance between the clinical and histopathological agreement was seen in $15(34.5 \%)$ cases and maximum clinico-histopathological correlation was seen in BB (100\%) followed by TT (57.1\%), BT (50\%), IL and BL (33.3\%) and $0 \%$ in LL.

The concordance rate was lower in the borderline groups with $33.3 \%$ in BL, 33\% in IL and least concordance of $16.7 \%$ in LL. However, the concordance for TT was higher than the borderline groups with $57.1 \%$. Histopathological analysis of the cases in the present study as shown in Table 3 was carried out with due attention to the epidermal atrophy, presence of clear sub-epidermal zone, dermal inflammatory infiltrate, presence and composition of granulomas, presence of giant cells and relative proportion of lymphocytes and foamy histiocytes in accordance with Ridley and Jopling histopathological criteria.

\begin{tabular}{|c|c|c|c|c|c|c|c|c|}
\hline \multirow{2}{*}{ Age } & \multicolumn{7}{|c|}{ Histopathological Diagnosis } & Total \\
\cline { 2 - 9 } & BB & BT & LL & TT & BL & IL & NS & \\
\hline $\begin{array}{c}0-10 \\
\text { Years }\end{array}$ & 0 & 2 & 0 & 0 & 0 & 0 & 0 & 2 \\
\hline $\begin{array}{c}11-20 \\
\text { Years }\end{array}$ & 0 & 0 & 0 & 1 & 1 & 1 & 0 & 3 \\
\hline $\begin{array}{c}21-30 \\
\text { Years }\end{array}$ & 0 & 2 & 2 & 3 & 1 & 1 & 1 & 10 \\
\hline $\begin{array}{c}31-40 \\
\text { Years }\end{array}$ & 0 & 2 & 3 & 1 & 3 & 2 & 0 & 11 \\
\hline $\begin{array}{c}41-50 \\
\text { Years }\end{array}$ & 2 & 1 & 2 & 1 & 1 & 1 & 1 & 9 \\
\hline $\begin{array}{c}51-60 \\
\text { Years }\end{array}$ & 0 & 1 & 5 & 0 & 1 & 1 & 0 & 8 \\
\hline $\begin{array}{c}>60 \\
\text { Years }\end{array}$ & 0 & 1 & 4 & 0 & 1 & 0 & 1 & 7 \\
\hline Total & $\mathbf{2}$ & $\mathbf{9}$ & $\mathbf{1 6}$ & $\mathbf{6}$ & $\mathbf{8}$ & $\mathbf{6}$ & $\mathbf{3}$ & $\mathbf{5 0}$ \\
\hline $\begin{array}{c}\text { Table 6. Correlation of Clinical and Histopathological } \\
\text { Classification in Leprosy Cases }\end{array}$
\end{tabular}

Out of 50 patients included in the study, 15 (30\%) presented a clinical suspicion of paucibacillary leprosy and $35(70 \%)$ of multibacillary leprosy. From the chi-square 
output table, we see that no significance level has been achieved. McNemar Bowker test table showing no systematic association between the above two variables at 95\% level of confidence. Hence, it concludes that there is no significant relationship between age wise patients and histopathological diagnosis.

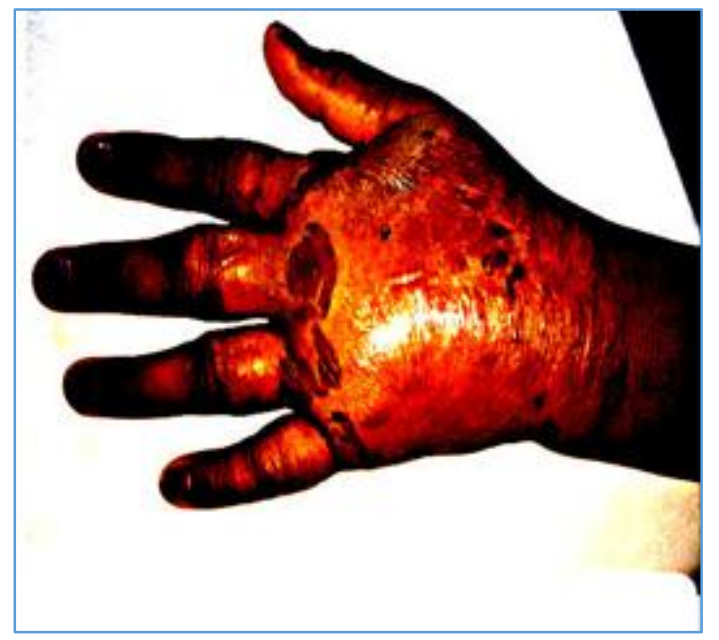

Pic 1-Tuberculoid Leprosy with swelling of hand.

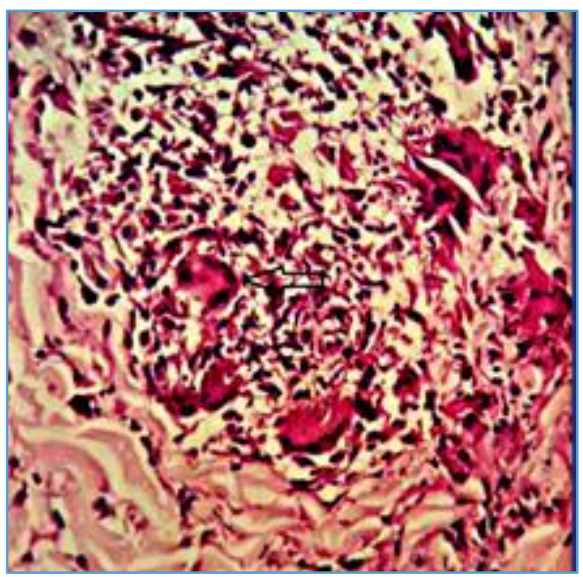

Pic 2. Histopathology of skin biopsy (H \& E 400x) showing Langhans foreign body giant cells, black arrow

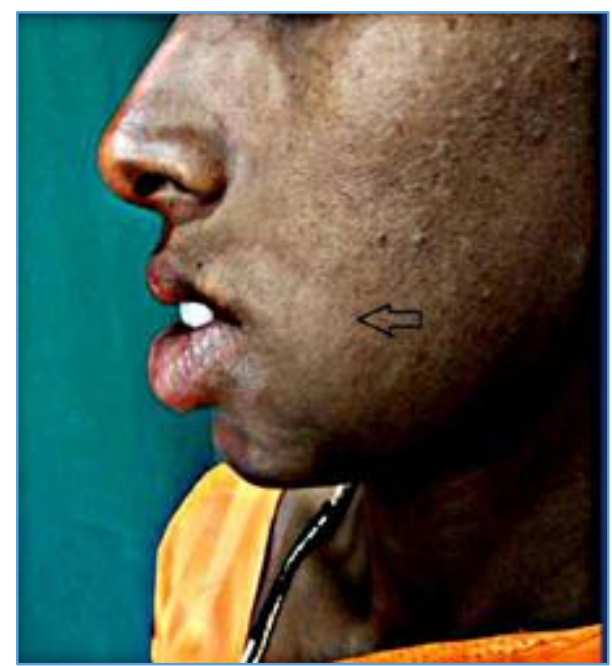

Pic 3. Borderline Tuberculoid Leprosy patient with lower lip swelling and hypopigmented patch on left cheek.

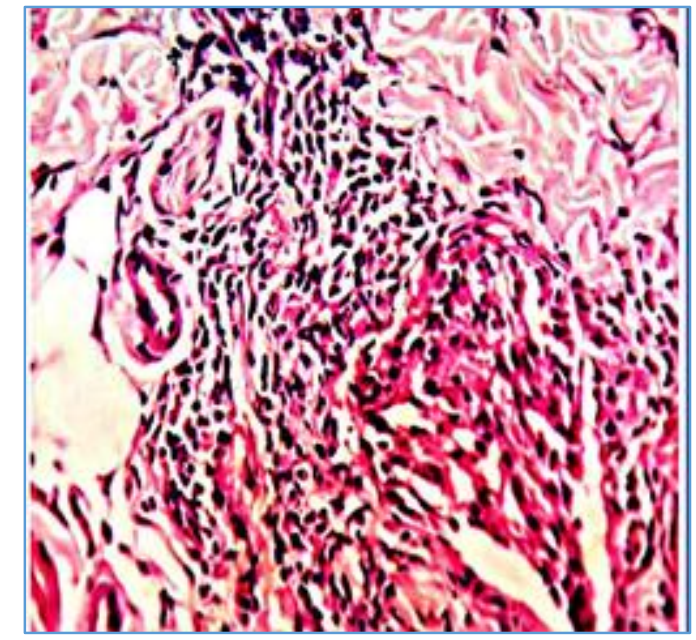

Pic 4. Histopathology of skin biopsy (H \& E Stain 400x) showing focal collection of macrophages in the dermis

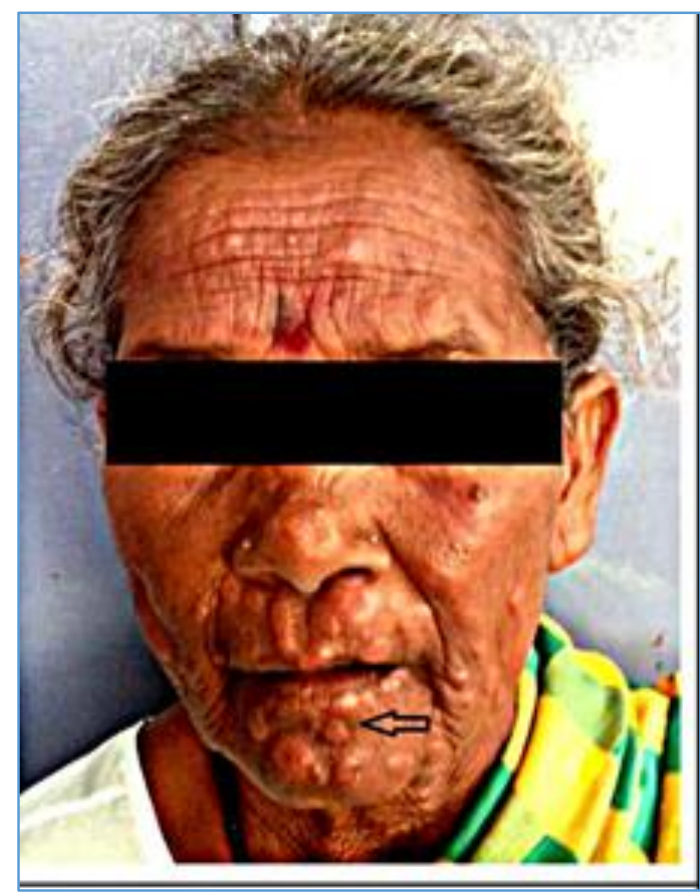

Pic 5. Lepromatous Leprosy with ENL reaction

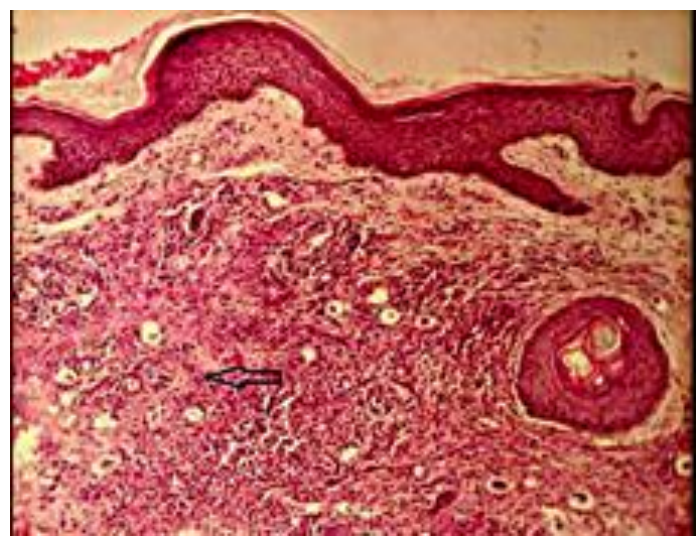

Pic 6. Histopathology of skin biopsy (H \& E stain 400x) showing dermal neutrophilic infiltrate amidst with macrophages 


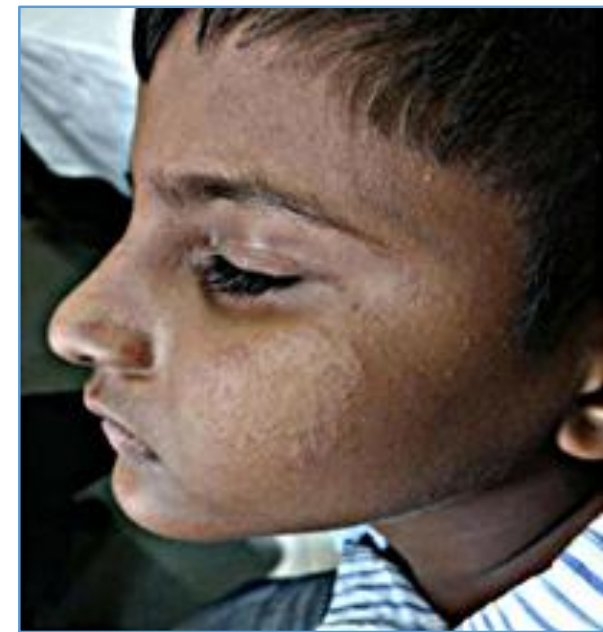

Pic 7. Indeterminate Leprosy with hypopigmented plaque over cheek

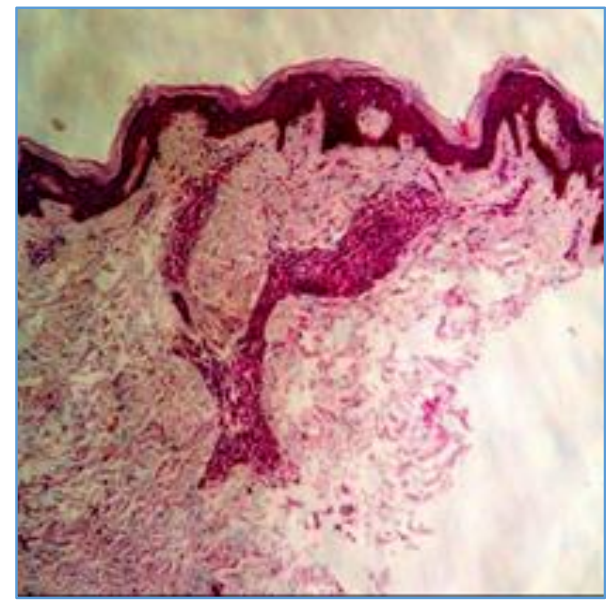

\section{Pic 8 Histopathology of skin biopsy (H \& E stain 400x) showing focal collection of foamy macrophages in the dermis}

\section{DISCUSSION}

Due to its clinical diversity and resemblance to other diseases, leprosy is difficult to diagnose clinically. The sex ratio was heavily skewed towards males (66\%). This is similar to other Indian studies undertaken by Gridhar $\mathrm{M}$ et al $(77.6 \%)^{7}$ and Bhushan et al (72.34\%). ${ }^{8}$ Mathur MC et al, however, observed $53.8 \%$ males in their study, while Moorthy et al observed $65.05 \%$ males. $^{9}$

The common age group affected in present study is between $31-40$ yrs. (22\%) and the second common age group affected was between $21-30$ yrs. (20\%) followed by 41 - 50 yrs. (18\%), 51 - 60 yrs. (16\%), 60+ yrs. (14\%), $11-20$ yrs. (6\%) and less than 10 yrs. (4\%). The mean age of the patients studied was $41.34+17.1$. In a study done by Moorthy BN et al, majority of patients were between 20 - 29 years $(20.70 \%)$. Children below 9 years were least affected (6.45\%). ${ }^{9}$ In present study also, youngest age affected was 7 years. In one series, age range was $6-72$ years and mean age was 35.9 years. ${ }^{10}$ In another study done in Green Pastures Hospital, Pokhara, the mean age was 41 years. ${ }^{11}$

In present study among 50 cases, 34 (68\%) cases showed correlation between clinical and histopathological diagnosis. Maximum correlation was observed in borderline Leprosy
(100\%) and borderline Lepromatous groups (100\%) followed by Lepromatous Leprosy (70\%), Indeterminate Leprosy (66.67\%) and Tuberculoid Leprosy (57.14\%). A poor correlation was seen in Borderline Tuberculoid leprosy.

Ridley and Jopling found agreement between clinical and histological types in 56 (68.3\%) out of 82 patients. Agreement in present study is almost similar to Ridley and Jopling study (68\%).

A similar study done by Jerath and Desai found agreement between clinical and histological types is $68.5 \%$, which is slightly more than present study (68\%).

A similar study done by Bhusan et al showed a concordance of $74.47 \%$ between the histological and clinical diagnosis out of 150 patients, which is more than present study (68\%).

A similar study done by Vargas-Ocampo $F$ et al ${ }^{12}$ found agreement between clinical and histological types in 2520 (42\%) out of 6000 cases patients, which is less than present study $(68 \%)$.

A similar study done by Kar et al showed a concordance of $70 \%$ between the histological and clinical diagnosis, which is more than present study (68\%).

A similar study done by Bhatia AS et al ${ }^{13}$ found agreement between clinical and histological types in 878 (69\%) out of 1276 cases patients, which is more than present study (68\%).

A similar study done by Kar PK et al ${ }^{14}$ found agreement between clinical and histological types in 84 (70\%) out of 120 patients, which is more than present study (68\%).

A similar study done by Nadkarni NS et $\mathrm{al}^{15}$ found agreement between clinical and histological types in 2160 $(81.8 \%)$ out of 2640 patients, which is more than present study $(68 \%)$.

A similar study done by Sehgal VN et al16 found agreement between clinical and histological types in 34 (33\%) out of 95 cases patients, which is less than present study $(68 \%)$.

A similar study done by Manandhar $U$ et $\mathrm{al}^{17}$ found agreement between clinical and histological types in 34 $(45.33 \%)$ out of 75 patients, which is less than present study (68\%).

A similar study done by Sharma et al showed a concordance of $53.44 \%$ between the histological and clinical diagnoses, which is less than present study (68\%).

A similar study done by Mitra $\mathrm{K}$ et al 18 found agreement between clinical and histological types in 1509 (57.16\%) out of 2640 patients. which is less than the present study (68\%).

A similar study done by Pandya $\mathrm{AN}$ et $\mathrm{al}^{19}$ found agreement between clinical and histological types in 29 (58\%) out of 50 patients, which is less than present study (68\%).

A similar study done by Moorthy et al showed a concordance of $62.63 \%$ out of 372 patients between the histological and clinical diagnosis which is less than present study (68\%).

A similar study done by Kalla $\mathrm{G}$ et $\mathrm{a}^{20}$ found agreement between clinical and histological types in 476 (64.7\%) out of 736 patients, which is less than present study (68\%). The agreement between the clinical and histopathological diagnosis of the lesion was $68 \%$. Other authors have reported percentage agreements ranging from $29.7 \%$ to $89.0 \%$. The greatest agreements have occurred with the polar forms and the smallest rates with the intermediate forms (Dimorphic). 
Table11: Comparative study of correlation in different

histopathology types by different authors.

\begin{tabular}{|c|c|c|c|c|c|c|c|}
\hline $\begin{array}{l}\text { Types } \\
\text { of } \\
\text { leprosy }\end{array}$ & \begin{tabular}{|l} 
Jerath \\
VP \\
et $\mathbf{a l}^{37}$
\end{tabular} & $\begin{array}{l}\text { Bhatia } \\
\text { AS } \\
\text { et }\left.a\right|^{38}\end{array}$ & \begin{tabular}{|l|} 
Nadkar \\
ni \\
NS \\
et al $^{40}$
\end{tabular} & $\begin{array}{l}\text { Kar PK } \\
\text { et a }\left.\right|^{39}\end{array}$ & $\begin{array}{l}\text { Kalla } \\
\mathbf{G} \\
\text { et } \mathbf{a l}^{35}\end{array}$ & \begin{tabular}{|l|} 
Moorth \\
$\mathbf{y}$ \\
BN \\
et $\mathrm{al}^{27}$
\end{tabular} & \begin{tabular}{|l|} 
Prese \\
nt \\
study
\end{tabular} \\
\hline TT & 74.5 & 50 & 97 & 87.5 & 76.7 & 46.15 & 57.14 \\
\hline BT & \begin{tabular}{|l|}
64.7 \\
\end{tabular} & 77 & 95 & 60.9 & 44.2 & 66.66 & 50 \\
\hline BB & 53.8 & 25 & 89 & 54.5 & 37 & 50 & 100 \\
\hline $\mathrm{BL}$ & 28.5 & 43 & 87 & 53.8 & \begin{tabular}{|l}
43.7 \\
\end{tabular} & 70 & 100 \\
\hline $\mathrm{LL}$ & 61.5 & 91 & 98 & 71.4 & 75.6 & 80 & 70 \\
\hline $\mathrm{IL}$ & 88.8 & 35 & & 81.2 & & 20 & 66.67 \\
\hline
\end{tabular}

Maximum concordance was observed in LL type of leprosy in studies by Mathur MC et al, Gridhar M et al,7 Moorthy et al, ${ }^{9}$ Nandkarni NS et al ${ }^{15}$ and Bhatia AS et al, ${ }^{13}$ but in present study $70 \%$ concordance was observed in LL type of leprosy which is less than BB and BL.

Maximum concordance was observed in Indeterminate type of leprosy in studies by Jerath VP et $\mathrm{al}^{21}$ (88.8\%), which is more than present study $(66.67 \%)$.

Maximum concordance was observed in tuberculoid type of leprosy in studies by Kar PK et al ${ }^{14}$ and Kalla G et al,20 which is more than present study (57.14\%).

As there is overlap in histopathologic features of different types of leprosy, morphology alone is not specific, thus adequate clinical data can help in good clinical pathologic correlation.

\section{CONCLUSION}

Leprosy, though reported to be eliminated, still continues to be one of the common infectious diseases in India. Skin biopsy is the investigation of choice for clinical diagnosis of leprosy as well as acts as a therapeutic guide.

\section{REFERENCES}

[1] Mohite RV, Mohite VR, Durgawale PM. Differential trend of leprosy in rural and urban area of Western Maharashtra. Indian J Lepr 2013;85(1):11-8.

[2] Mathur MC, Ghimire RB, Shrestha P, et al. Clinico histopathological correlation in Leprosy. Kathmandu Univ Med J 2011;9(36):248-51.

[3] Jopling WH, McDougall AC. Definition, epidemiology and world distribution. Hand Book of leprosy. $1^{\text {st }}$ Indian edn. Delhi: CBS Publishers 1992: p. 1-7.

[4] Nayak SV, Shivarudrappa AS, Nagarajappa AH, et al. Role of modified rapid AFB method in histopathological sections of Hansen's disease. Ind J Dermatol Venereol Leprol 2003;69(2):173-4.

[5] Job CK, Chacko CJ. A modification of Fite's stain for demonstration of $\mathrm{M}$. leprae in tissue sections. Ind J Lepr 1986;58(1):17-8.
[6] Chacko CJG. Leprosy pathology. In: Valia RG, Valia AR. eds. Textbook and Atlas of Dermatology. $1^{\text {st }}$ edn. Mumbai: Bhalani Publishing House 1994: p. 1340-9.

[7] Giridhar M, Arora G, Lajpal $K$, et al. Clinicohistopathological concordance in Leprosy - a clinical, histopathological and bacteriological study of 100 cases. Indian J Lepr 2012;84(3):217-25.

[8] Bhushan P, Sardana K, Koranne RV, et al. Diagnosing multibacillary leprosy: a comparative evaluation of diagnostic accuracy of slit-skin smear, bacterial index of granuloma and WHO operational classification. Indian J Dermatol Venereol Leprol 2008;74(4):322-6.

[9] Moorthy BN, Kumar P, Chatura KR, et al. Histopathological correlation of skin biopsies in leprosy. Indian J Dermatol Venereol Leprol 2001;67(6):299-301.

[10] Robertson LM, Nicholls PG, Butlin R. Delay in presentation and start of treatment in leprosy: experience in an out-patient clinic in Nepal. Lepr Rev 2000;71(4):511-6.

[11] Van Brakel WH, Khawas IB, Lucas SB. Reaction in leprosy: an epidemiological study of 386 patient in west Nepal. Lepr Rev 1994;65(3):190-203.

[12] Lucus SB, Ridley DS. The use of histopathology in leprosy diagnosis and research. Lepr Rev 1989;60(4):257-62.

[13] Bhatia AS, Katoch K, Narayanan RB, et al. Clinical and histopathological correlation in the classification of leprosy. Int J Lepr and Other Mycobact Dis 1993;61(3):433-8.

[14] Kar PK, Arora PN, Ramasastry CV, et al. A clinicopathological study of macular lesions in leprosy. Indian J Lepr 1994;66(4):435-42.

[15] Nandkarni NS, Rege VL. Significance of histopathological classification in leprosy. Ind J Lepr 1999;71(3):325-32.

[16] Sehgal VN, Rege VL, Reys M. Correlation between clinical and histopathologic classification in leprosy. Int J Lepr and Other Mycobact Dis 1977;45(3):278-80.

[17] Manandhar U, Adhikari RC, Sayami G. Clinicohistopathological correlation of skin biopsies in leprosy. Journal of Pathology of Nepal 2013;3(6):4528.

[18] Mitra K, Biswas S, Saha B, et al. Correlation between clinical and histopathological criteria for the classification of leprosy. Ind J Dermatol Venereol Leprol 2001;46(3):135-7.

[19] Pandya AN, Tailor HJ. Clinoco - histopathological correlation of leprosy. Ind J Dermatol Venerol Leprol 2008;74(2):174-6.

[20] Kalla G, Salodkar A, Kachhawa D. Clinical and histopathological correlation in leprosy. Int J Lepr and Other Mycobact Dis 2000;68)2):184-5.

[21] Jerath VP, Desai SR. Diversities in clinical and histopathological classification of leprosy. Leprosy in India 1982;54(1):130-4. 